\title{
Effect of ageing treatment on wear properties and electrical conductivity of $\mathrm{Cu}-\mathrm{Cr}-\mathrm{Zr}$ alloy
}

\author{
IBRAHIM SAĞLAM ${ }^{1}$, DURSUN ÖZYÜREK ${ }^{2} *$ and KERIM ÇETINKAYA ${ }^{1}$ \\ ${ }^{1}$ Technical Education Faculty, Department of Machine Education, ${ }^{2}$ Department of Metal Education, \\ Karabuk University, Karabük 078100, Turkey
}

MS received 5 December 2009; revised 7 September 2010

\begin{abstract}
In this study, the effect of ageing processes on the wear behaviour and electrical conductivity was investigated. Prior to solid solution heat treatment at $920^{\circ} \mathrm{C}$ and ageing at $470^{\circ} \mathrm{C}, 500^{\circ} \mathrm{C}$ and $530^{\circ} \mathrm{C}$ for $1 \mathrm{~h}, 2 \mathrm{~h}$ and $3 \mathrm{~h}$, respectively, the prepared samples were homogenized at $920^{\circ} \mathrm{C}$ for $1 \mathrm{~h}$. After the ageing processes, all samples were characterized in terms of electrical conductivity, scanning electron microscope (with energy dispersive X-ray spectrum (EDS)) and hardness (HV5). In wear tests, pin-on-disc type standard wearing unit was used. As a result, starting from $1 \mathrm{~h}$ aged specimens, orderly increase of electrical conductivity was defined. From EDS analyses it was observed that $\mathrm{Cr}$ rate increases as precipitates grow. With increase of $\mathrm{Cr}$ rate there was also a defined rise of electrical conductivity. From the wear tests, it was observed that the least wear loss was in $\mathrm{Cu}-\mathrm{Cr}-\mathrm{Zr}$ alloy aged at $500^{\circ} \mathrm{C}$ for $2 \mathrm{~h}$ and the most wear loss was in specimens aged at $530^{\circ} \mathrm{C}$ for $2 \mathrm{~h}$. Furthermore, it was observed that the friction coefficient values resulting from wear rate were overlapped with hardness results and there is a decrease tendency of friction coefficient as wear distance increases.
\end{abstract}

Keywords. $\mathrm{Cu}-\mathrm{Cr}-\mathrm{Zr}$; wear; ageing treatment; electrical conductivity.

\section{Introduction}

$\mathrm{Cu}-\mathrm{Cr}-\mathrm{Zr}$ alloys are used in applications in many industrial areas, mostly in automotive sector, because of their high electrical and thermal conductivities (Durashevich et al 2002; Liu et al 2005; Li et al 2007). Along with electrical and thermal characteristics, it is also possible to improve mechanical characteristics of these alloys. However, it is difficult to improve the characteristics of these alloys with traditional heat treatment methods. Ageing treatment is one of the most important methods that increases mechanical characteristics of copper alloys without decreasing their conductivity characteristics (Liu et al 1999; Holzwarth et al 2000; Su et al 2007). Dispersion and size of second phase particulates that are formed by ageing in $\mathrm{Cu}-\mathrm{Cr}-\mathrm{Zr}$ alloys are the most important factors that increase the strength and hardness of the alloy (Nagarjuna et al 2001; Qi et al 2003). In some researches, it is emphasized that in over-saturated matrix, second phase particulates which are Cr-rich, compatible and thindispersed provide high resistance and particulates coarsened because of over-ageing in parallel with ageing temperature and time form a incoherent inter surface and affect resistance negatively (Fujii et al 2000; Tu et al 2002).

\footnotetext{
*Author for correspondence (dozyurek@ karabuk.edu.tr)
}

$\mathrm{Cu}$ alloys are ductile type alloys whose wear behaviour is similar to that of other ductile type materials like Al. As research results show that the second phase provided in the ageing conditions increase the materials resistance and improves wear characteristics (Rigney 2000; Yildiz et al 2007; Yaşar et al 2009). Damages occurred because of over-deformation on sample contact surface in $\mathrm{Cu}-\mathrm{Cr}-$ $\mathrm{Zr}$ alloys at the time of wear tests can be explained with different wear mechanisms such as oxidative, abrasive and adhesive based on the applied load and sliding speed (Qi et al 2003; Straffelini et al 2005). In this study, to increase resistance and electrical conductivity of $\mathrm{Cu}-\mathrm{Cr}-\mathrm{Zr}$ alloys and to increase the optimum resistance/ conductivity values, ageing heat proceeds have been applied. In experimental studies, determining the effect of particulates that are formed in the ageing on electrical conductivity and wear resistance was aimed.

\section{Materials and methods}

$\mathrm{Cu}-\mathrm{Cr}-\mathrm{Zr}$ alloy which is used in this study, and contains $0.65 \% \mathrm{Cr}$ and $0.07 \% \mathrm{Zr}$ was taken from De Le Bronze Industrial firm. Samples were fast-cooled after being taken for solution at $920^{\circ} \mathrm{C}$ for $1 \mathrm{~h}$ in argon atmosphere. Water quenched specimens were aged at $470^{\circ} \mathrm{C}, 500^{\circ} \mathrm{C}$ and $530^{\circ} \mathrm{C}$ for three different periods ( $1 \mathrm{~h}, 2 \mathrm{~h}$ and $3 \mathrm{~h}$ ) and cooled in an electric resistance furnace at room temperature. Electrical conductivity was measured in 

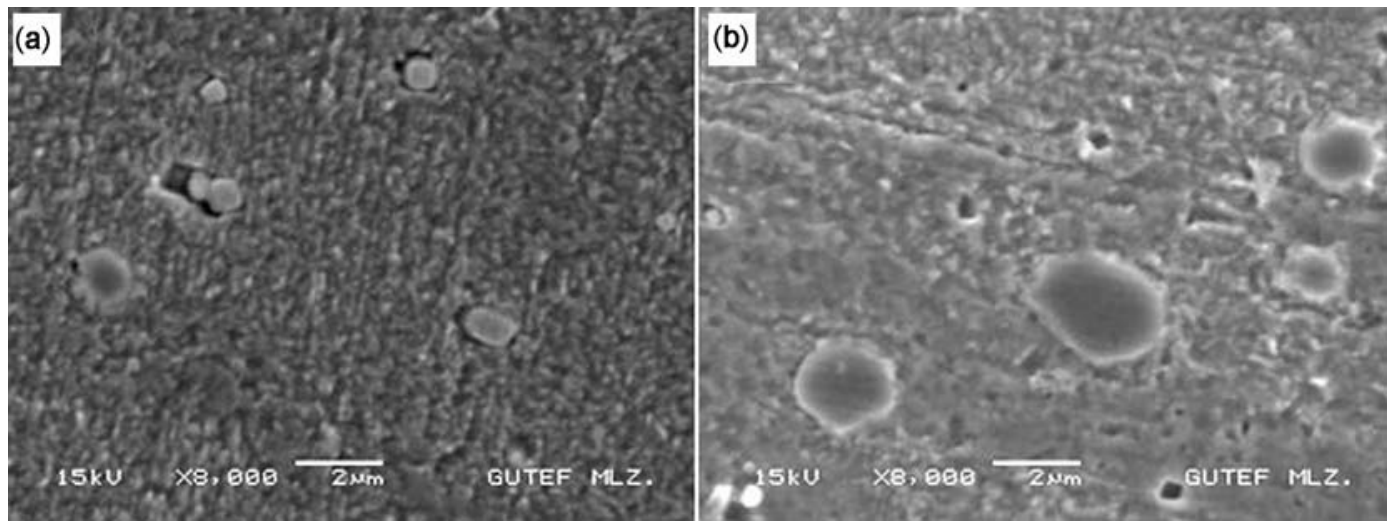

Figure 1. SEM images of non-aged (a) and aged at $500^{\circ} \mathrm{C}$ for $2 \mathrm{~h}(\mathbf{b}) \mathrm{Cu}-\mathrm{Cr}-\mathrm{Zr}$ alloy.

Solartron 1296 Elektrik interface, SI 1287 Elektrochemical interface. For microstructure analyses, samples were prepared with standard metalographic processes and etched for 30-60 sn with $50 \mathrm{ml}$ ethanol, $1 \mathrm{ml} \mathrm{HF}, 8 \mathrm{ml} \mathrm{HNO}_{3}$ and $4 \mathrm{ml} \mathrm{HC1}$. Prepared specimens were examined with JEOL JSM-6060 scanning electron microscope (SEM). Hardness measurements were carried out in (HV5) AFFRI universal hardness measurement device. Wear tests were carried out in pin-on-disk type wear testing device. For wear tests parameters used were $45 \mathrm{~N}$ load, four different wear distances $(250,500,750$ and $1000 \mathrm{~m})$ and $2 \mathrm{~m} / \mathrm{s}$ sliding speed. A steel disc (AISI 4140) with 56 Rc hardness, $\phi 230 \mathrm{~mm}$ size and $20 \mathrm{~mm}$ thickness was used for the tests. The surfaces of all samples were smoothened with 1200 grid emery and were cleaned with acetone. Occurred material loss was defined by comparing specimen masses after wear tests with their original masses. Wear rate was defined by measuring mass loss of alloy at the end of every sliding distance. Wear surfaces of specimens were analysed with SEM.

\section{Results and discussion}

\subsection{Microstructure characterization}

Electrical conductivity and wear behaviour of $\mathrm{Cu}-\mathrm{Cr}-\mathrm{Zr}$ alloy at a larger rate depend on the ageing condition of alloy. Dimension of precipitate formed in microstructure by wear depends on wear temperature and period. Wear started forming Guiner-Preston (GP) parts at low temperatures, when at higher temperatures transforms into over-ageing with causes precipitate coarse. Figure 1 shows SEM images of non-aged (figure 1a) and aged (figure $1 \mathrm{~b}$ ) at $500^{\circ} \mathrm{C}$ for $2 \mathrm{~h} \mathrm{Cu}-\mathrm{Cr}-\mathrm{Zr}$ alloy.

The SEM images (figures $1 \mathrm{a}, \mathrm{b}$ ) of $\mathrm{Cu}-\mathrm{Cr}-\mathrm{Zr}$ alloy show that in microstructures of both precipitate and specimens aged at $500^{\circ} \mathrm{C}$ for $2 \mathrm{~h}$, there are precipitates and hexagon-shaped particulates formed with ageing. From EDS analysis carried out in SEM, Cr-rich parts formed inside the $\mathrm{Cu}$ matrix that grow by effect of ageing

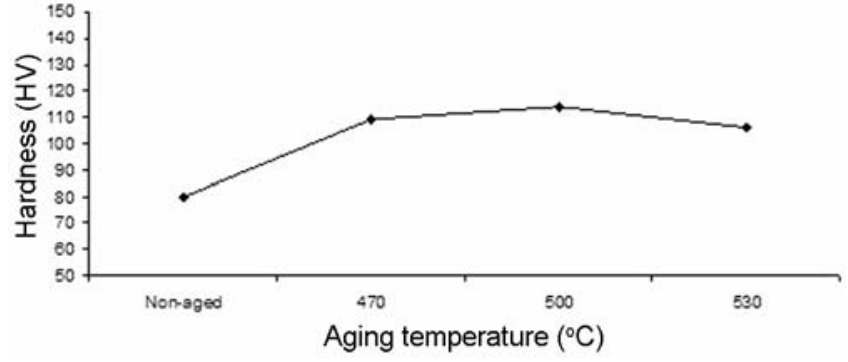

Figure 2. Hardness changes of aged $\mathrm{Cu}-\mathrm{Cr}-\mathrm{Zr}$ alloy at different temperatures and periods.

(Tu et al 2002). With an increase of ageing temperature, there is a decrease in hardness of alloy due to the effect of increase occurred in precipitates (figure 2).

In figure 2, effect of ageing temperature on Vickers hardness of alloy is seen. As hardness of $\mathrm{Cu}-\mathrm{Cr}-\mathrm{Zr}$ alloy which was $80 \mathrm{HV}$ before the ageing treatment was compared with hardness value taken after thermal treatment, an increase of hardness in an evident form is appeared. In a study made earlier (Qi et al 2003), it was found that the reason for ageing endurance of $\mathrm{Cu}-\mathrm{Cr}-\mathrm{Zr}$ alloy was (Heusler phase) homogeneous dispersion of semi-stable and complex intermetallic precipitates occurred in the structure. GP parts and over-ageing are formed in the structure with ageing affecting the endurance and hardness of the alloy. Ageing at low temperatures, provides formation of GP parts and at high temperatures decreases endurance and hardness of material because of overageing. A study made by Su et al (2005) also supports these results. Hardness increase occurred in $\mathrm{Cu}$ matrix can be explained by Orowan mechanism.

$$
\Delta \tau=k f^{1 / 2} R^{-1},
$$

where $\Delta \tau$ is the increase in shear stress, $k$ a constant, $f$ the volume fraction of precipitates and $R$ the diameter of precipitates (Su et al 2005). Volume fraction of precipitates with small diameter increase the value of $\Delta \tau$ and higher hardness values are obtained. Furthermore, this condition is also explained by dislocations formed in the 
structure with ageing and occurred through precipitates and resistance of dispersion obtained with precipitates formation. In another study made earlier, it was found that hardness value reached the highest point when ageing done at $500^{\circ} \mathrm{C}$ (Vinogradov 2002). EDS analysis shows that precipitates formed in microstructure with ageing thermal treatment are $\mathrm{Cr}$-rich parts $(57 \% \mathrm{Cu}$ and $41 \% \mathrm{Cr}$ ). It was observed that $\mathrm{Cr}$ rate increases as the dimension of $\mathrm{Cr}$-rich precipitate formed at $2 \mathrm{~h}$ ageing thermal treatment grows.

\subsection{Electrical conductivity}

$\mathrm{Cu}$ alloys are widely used at industrial fields because of their high electrical conductivity. Hence, in this study electrical conductivities of $\mathrm{Cu}-\mathrm{Cr}-\mathrm{Zr}$ alloy were measured before and after ageing. In table 1, changes of electrical conductivity measured on the basis of ageing temperature and period of $\mathrm{Cu}-\mathrm{Cr}-\mathrm{Zr}$ alloy are given.

As seen in table 1, the highest conductivity value was obtained in specimen aged at $530^{\circ} \mathrm{C}$ for $3 \mathrm{~h}$. From figure 2 , hardness results, it is observed that in materials included into over-ageing period a slight increase in conductivity continues when a decrease in hardness occurs. This is because hardness is growing parallel to ageing period and $\mathrm{Cr}$-rich particulates in $\mathrm{Cu}$ matrix ( $\mathrm{Tu}$ et al 2002). Ageing and second phase particles that occurred in the structure increases the strength in the crystal lattice. This increase in strength causes distortion and decreases the electric conductivity. However, due to the increase of $\mathrm{Cr}$ rate on the stages (the growth of precipitates), there will be an increase in the electric conductivity. Distortion that happens in the lattice because of second phase particles that are formed in the structure by ageing and two different mechanisms that compensate each other with the increase in the $\mathrm{Cr}$ rate during the growth of the precipitates will occur. Hence, there is an increase in both the growth of precipitates and electric conductivity. Precipitates in $\mathrm{Cu}$ matrix because of $\mathrm{Cr}$-rich coarse phases and a decrease in electrons scattered on the surfaces provide a

Table 1. Electrical conductivity (IACS \%) values according to ageing temperature and period.

\begin{tabular}{lcc}
\hline $\begin{array}{l}\text { Ageing } \\
\text { temperature }\left({ }^{\circ} \mathrm{C}\right)\end{array}$ & $\begin{array}{c}\text { Ageing } \\
\text { time }(\mathrm{h})\end{array}$ & $\begin{array}{c}\text { Electrical conductivity } \\
\text { (IACS \%) }\end{array}$ \\
\hline Non-aged & - & $81 \cdot 25$ \\
470 & 1 & $68 \cdot 7$ \\
470 & 2 & 72 \\
470 & 3 & $76 \cdot 5$ \\
500 & 1 & $72 \cdot 26$ \\
500 & 2 & $75 \cdot 26$ \\
500 & 3 & $80 \cdot 79$ \\
530 & 1 & $77 \cdot 03$ \\
530 & 2 & $79 \cdot 6$ \\
530 & 3 & 89 \\
\hline
\end{tabular}

contribution to an increase in electrical conductivity. In a study done by Su et al (2005), it is emphasized that Crrich parts formed through the piece, border increase the hardness and electrical conductivity. Hence obtained hardness and electrical conductivity results in this study show similarity with the results of study made by $\mathrm{Su}$ et al (2005).

\subsection{Wear tests}

In figure $3, \mathrm{Cu}-\mathrm{Cr}-\mathrm{Zr}$ alloy aged at different temperatures for $2 \mathrm{~h}$ and wear losses obtained in steel consisted tribo-system in $45 \mathrm{~N}$ load and various sliding distances are given. According to wear loss results (figure 3), effect of ageing temperature on wear endurance of alloy is seen.

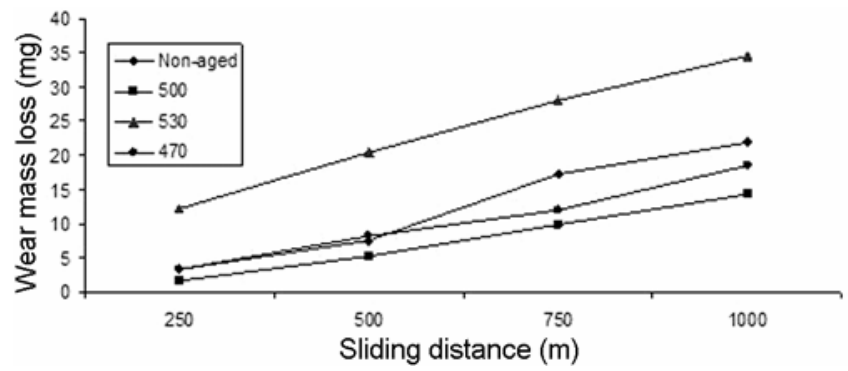

Figure 3. Wear losses occurred under $45 \mathrm{~N}$ load of $\mathrm{Cu}-\mathrm{Cr}-\mathrm{Zr}$ alloy aged at different temperatures for $2 \mathrm{~h}$.

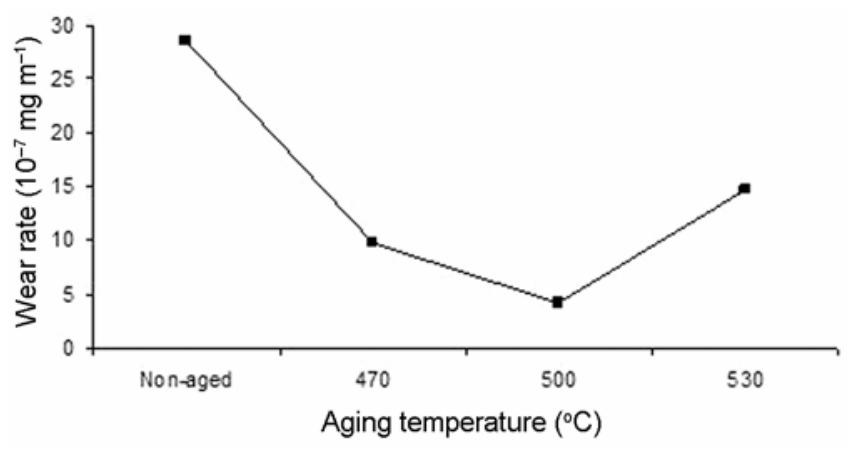

Figure 4. Effect of ageing temperature on wear rate.

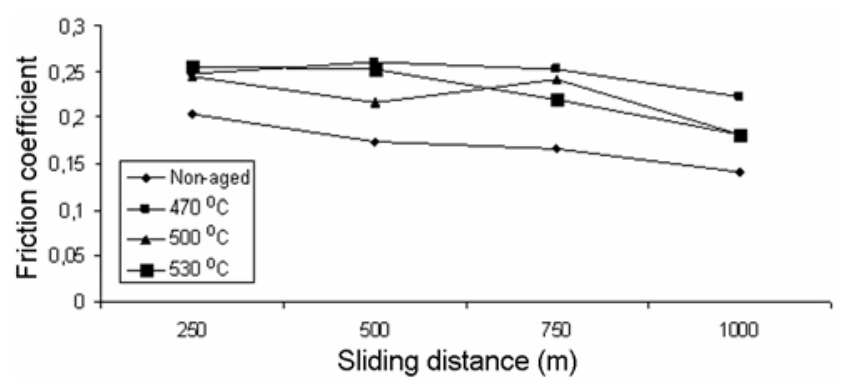

Figure 5. Depending on wear distance occurred changes in friction coefficient in $\mathrm{Cu}-\mathrm{Cr}-\mathrm{Zr}$ alloy aged at different temperatures. 

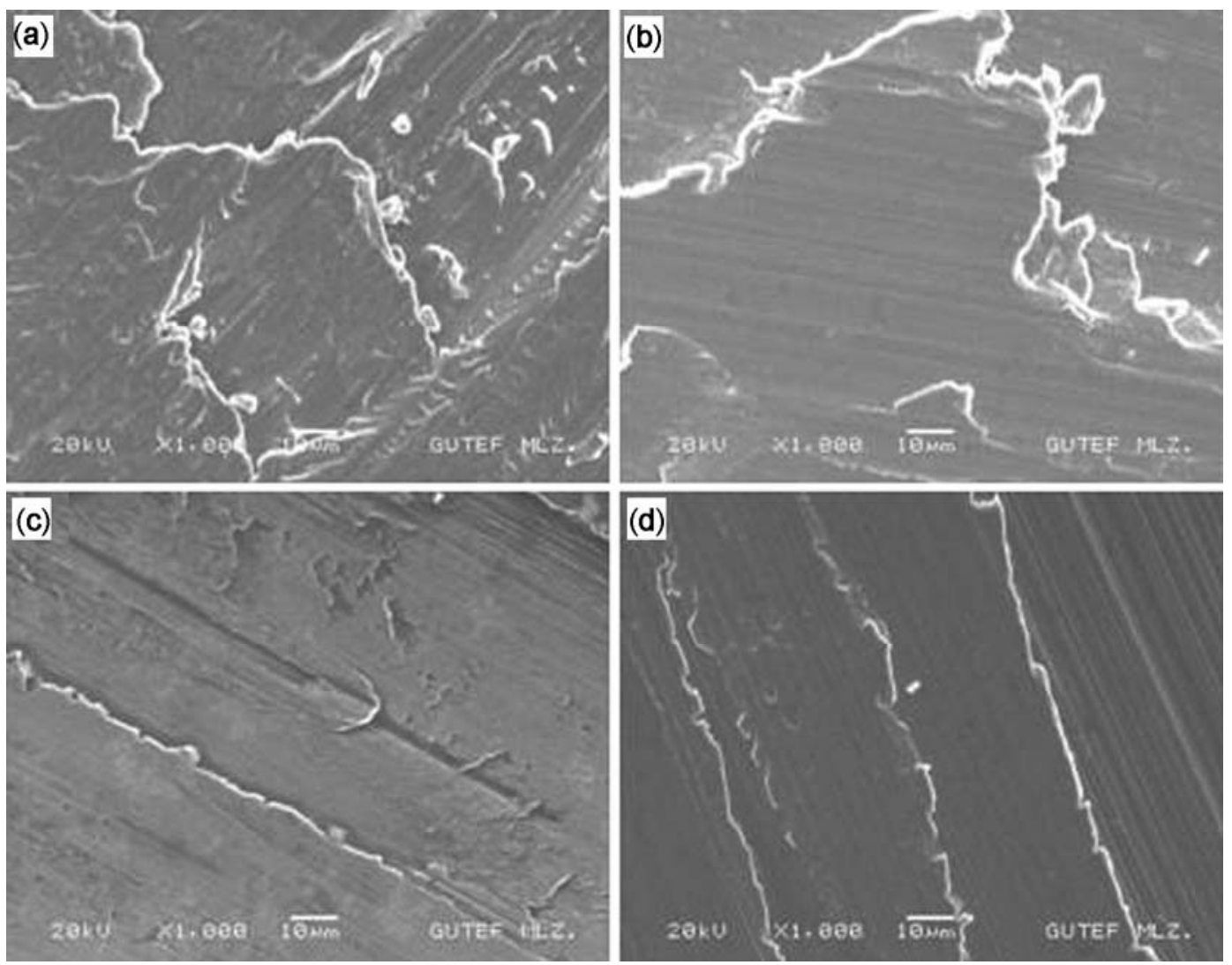

Figure 6. SEM images of wear surface of $\mathrm{Cu}-\mathrm{Cr}-\mathrm{Zr}$ alloy aged at different temperatures for $2 \mathrm{~h}$ and tested under $45 \mathrm{~N}$ load; (a) non-aged, (b) $470^{\circ} \mathrm{C}$, (c) $500^{\circ} \mathrm{C}$ and (d) $530^{\circ} \mathrm{C}$.

As the most wear loss was expected in non-aged specimen, its origination in specimens aged at $530^{\circ} \mathrm{C}$ was unexpected. This situation can be explained in two ways. Firstly, even there is a small possibility it may be the errors exist in the structure of $\mathrm{Cu}-\mathrm{Cr}-\mathrm{Zr}$ alloy. Secondly, it may be an increase of wear loss due to the effect of fractures occurred during the wear tests because of over growth of dimensions of precipitates formed in the structure with ageing. Second hypothesis is stronger because the hardness of alloy aged at $530^{\circ} \mathrm{C}$ is higher than nonaged alloy. Since the ductile $\mathrm{Cu}$ matrix is more easily deformed, it is easier to compensate the applied load. For this reason, fracture possibility of harder than non-aged specimens alloy aged at $530^{\circ} \mathrm{C}$ for $2 \mathrm{~h}$ occurring on contact surface increases. In figure 4, changes occurred due to ageing temperature in wear rates of $\mathrm{Cu}-\mathrm{Cr}-\mathrm{Zr}$ alloy is given.

Figure 4 shows that at the beginning wear rate decreases depending on the increase in ageing temperature, but there is an evident increase tendency in wear rate of alloy aged at $530^{\circ} \mathrm{C}$. This condition derives from the microstructure of the material. Effect of hardness and microstructure of the alloy on determination of wear behaviour of $\mathrm{Cu}$ alloys is extended. Dimensions of second phase precipitates formed in the structure with ageing reach the most ideal dimensions at $500^{\circ} \mathrm{C}$. This result is shown in figure 2. Precipitates formed in the structure with ageing of $\mathrm{Cu}-\mathrm{Cr}-\mathrm{Zr}$ alloy at $530^{\circ} \mathrm{C}$ are included into over-ageing period. By over-ageing coarse precipitates, hardness and endurance values decrease. Depending on this while the wear rate of aged $\mathrm{Cu}-\mathrm{Cr}-\mathrm{Zr}$ alloy increased the hardness of the materials decreased. In figure 5, depending on wear distance occurred changes in friction coefficient in $\mathrm{Cu}-\mathrm{Cr}-\mathrm{Zr}$ alloy aged at different temperatures are given.

As shown in figure 5, in $45 \mathrm{~N}$ load applied specimens as sliding distance increases, a decrease even in a very small measure occurs in friction coefficient. This is due to the effect of consistent temperature on contact surface of the specimen and the steel disc during the wear tests. With an increase in sliding distance, formation of oxide film layer occurs on the surface of the specimen during the friction. The most important factor which determines wear behaviour of $\mathrm{Cu}-\mathrm{Cr}-\mathrm{Zr}$ alloy and changes in friction coefficient in dry sliding conditions is the formation of oxide layer on the contact surface. The oxide layer protects the below metal surface when metal-metal contact occurs and acts as a solid lubricant. Adhesion between the specimen and the steel equivalent disc is higher than between the oxide layer and the steel disc. 
Hence, the friction coefficient decreases. An increase of temperature occurred during the wear tests decreases the hardness of $\mathrm{Cu}-\mathrm{Cr}-\mathrm{Zr}$ alloy, because of this it can be said that an increase in sliding distance increases the ratio of wear rate. In figure 6, SEM images of wear surface of $\mathrm{Cu}-\mathrm{Cr}-\mathrm{Zr}$ alloy aged at different temperatures and periods and tested under $45 \mathrm{~N}$ load are given (Saglam 2006).

From the worn surface images shown in figure 6, depending on increase in sliding distance, plastic deformation occurs on specimen surfaces. Continual scratches occurred on worn surfaces and micro-cracks based on fatigue indicate adhesive wear mechanism. This wear mechanism is derived from high micro-shear tension occurred on specimen surface during the tests. In figure 7, material transfer occurred between specimen and steel disc sliding appear clearer in EDS analysis taken from the worn surface of $\mathrm{Cu}-\mathrm{Cr}-\mathrm{Zr}$ alloy.

According to EDS results shown in figure 7, it appears that $\mathrm{Fe}, \mathrm{Co}$ and $\mathrm{Ni}$ are on the surface of aged $\mathrm{Cu}-\mathrm{Cr}-\mathrm{Zr}$ alloy. This condition shows material transfer between specimen and steel disc with effect of load also during the sliding. With an increase in sliding distance, high plastic deformation occurs on specimens' surfaces which causes the cracks in the beginning, then the growth of these cracks occur in advancing stages of wear and finally the material loss occurs. In a study made by Qi et al (2003), it is defined that formation of thin second phase precipitates formed in the structure with ageing, increases the endurance and because of the layer formed on the surface, at increasing speeds there is an intense

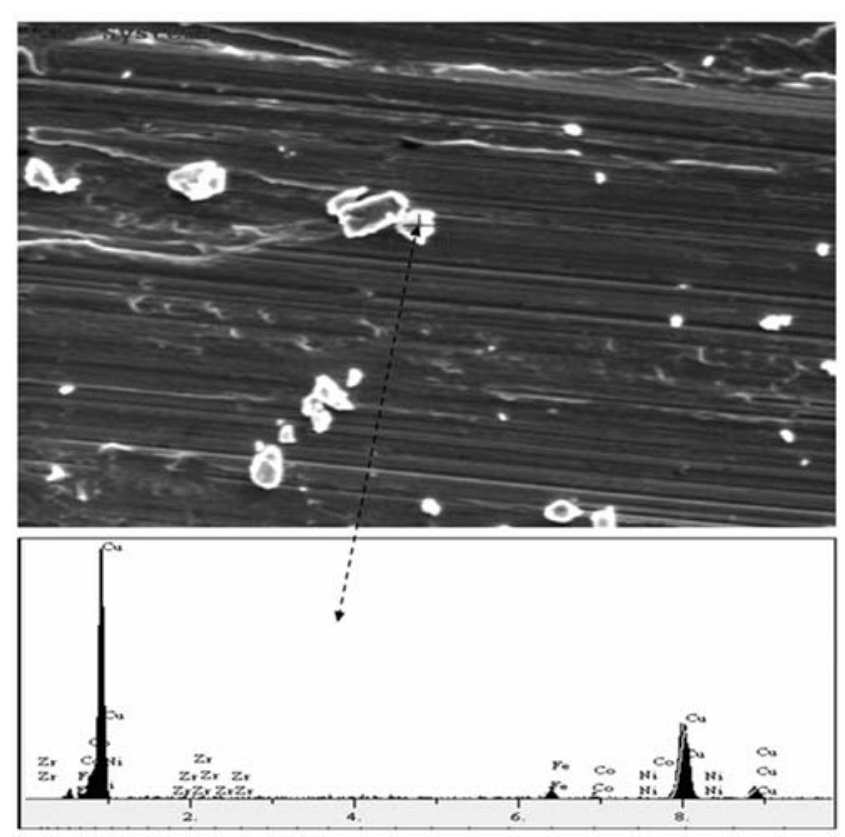

Figure 7. Wear surface SEM and EDS analyses results. abrasive wear. It is thought that as a result of $\mathrm{Cu}-\mathrm{Cr}-\mathrm{Zr}$ alloy ageing, with increase in the hardness of alloy second phase particulates formed in the structure pressure abrasive wear, counter to that adhesive wear mechanism gets more active state.

\section{Conclusions}

In this study, electrical conductivities were analysed by ageing $\mathrm{Cu}-\mathrm{Cr}-\mathrm{Zr}$ alloy which has high endurance and wear resistance (hence it is use in the automotive industry) and in the electrical flow conduction at $470^{\circ} \mathrm{C}, 500^{\circ} \mathrm{C}$ and $530^{\circ} \mathrm{C}$ temperatures for $1 \mathrm{~h}, 2 \mathrm{~h}$ and $3 \mathrm{~h}$, respectively. Furthermore, in specimens aged for $2 \mathrm{~h}$ wear tests were carried out. Results obtained from the study are summarized below:

(I) High hardness values in $\mathrm{Cu}-\mathrm{Cr}-\mathrm{Zr}$ alloy were obtained by ageing thermal treatment. This is due to the dislocations formed in the structure with ageing, occurred through precipitates and the resistance of dispersion obtained with precipitates formation.

(II) When SEM images and EDS analysis of $\mathrm{Cu}-\mathrm{Cr}-\mathrm{Zr}$ alloys are analysed, after ageing thermal treatment, size of precipitate increases with increasing measure of chrome which is a second phase. It was observed that enlarged $\mathrm{Cr}$-rich precipitates increase the electrical conductivity.

(III) In electrical conductivity tests of $\mathrm{Cu}-\mathrm{Cr}-\mathrm{Zr}$ alloys, the highest conductivity value was obtained by ageing at $530^{\circ} \mathrm{C}$ for $3 \mathrm{~h}$. When the hardness results are considered, as in materials included into over-ageing period hardness decreases, there is an increase in conductivity. Hard precipitate formed in the structure with ageing thermal treatment decreases electrical conductivity $\left(470^{\circ} \mathrm{C}\right)$. Due to this, by selecting appropriate ageing conditions in precipitate hardening, conductivity and endurance can be increased together $\left(500^{\circ} \mathrm{C}\right)$.

(IV) After ageing thermal treatment, an increase in the hardness by second phase particulates in wear resistance occurs. Because of low hardness value of non-aged $\mathrm{Cu}-$ $\mathrm{Cr}-\mathrm{Zr}$ alloy, the most wear measure was seen in this material.

(V) Second phase precipitates formed in the structure by ageing thermal treatment of $\mathrm{Cu}-\mathrm{Cr}-\mathrm{Zr}$ alloy at $530^{\circ} \mathrm{C}$ are included into the over growth (over-ageing) period and as a result of over-ageing growth, precipitates during the deformation are easily passed by dislocations and with this a decrease in wear resistance occurs.

(VI) It is defined that at the end of wear tests the least wear loss has $\mathrm{Cu}-\mathrm{Cr}-\mathrm{Zr}$ alloy aged at $500^{\circ} \mathrm{C}$ for $2 \mathrm{~h}$. The most wear loss was registered in the specimens aged at $530^{\circ} \mathrm{C}$ for $2 \mathrm{~h}$. As wear rates were analysed, it was defined that as wear distance of obtained values overlapped with hardness results increases, a decrease tendency occurs in friction coefficients. 


\section{References}

Durashevich G, Cvetkovski V and Jovanovich V 2002 Bull. Mater. Sci. 2559

Fujii T, Nakazawa H, Kato M and Dahmen U 2000 Acta Metall. 481033

Holzwarth U, Pisoni M, Scholz R, Stamm H and Volcan A 2000 J. Nucl. Mater. 27919

Li H, Xie S, Mi X and Wu P 2007 J. Mater. Sci. Technol. 23795

Liu P, Kang B X, Cao X G, Huang J L, Yen B and Gu H C 1999 Mater. Sci. Eng. A265 262

Liu P, Su J H, Dong Q and Li H, 2005 J. Mater. Sci. Technol. 21475

Nagarjuna S, Sharma K K, Sudhakar I and Sarma D S 2001 Mater. Sci. Eng. A313 251
Qi W X et al 2003 Mater. Sci. Eng. A343 89

Rigney D A 2001 Wear 245

Saglam I 2006 An investigation on wear behaviour electrical conductivity of $\mathrm{Cu}-\mathrm{Cr}-\mathrm{Zr}$ alloy, M.Sc. thesis

Straffelini G, Maines L, Pellizzari M and Scardi P 2005 Wear 259506

Su J H, Dong Q M, Liu P, Li H J and Kang B X 2005 Mater. Sci. Eng. A392 422

Su J H, Li H J, Liu P, Dong Q M and Li A J 2007 Comput. Mater. Sci. 38697

Tu J P et al 2002 Wear 2491021

Vinogradov A 2002 Acta Mater. 501639

Yaşar M and Altunpak Y 2009 Mater. Design 30878

Yildiz H B and Yașar M 2007 Metallofiz. Noveishie Tekhnol. 291659 